\title{
Analysis of Factors Affecting Brand Loyalty: A Case Study of Janji Jiwa Coffee
}

\author{
Danu Triwinarko Widodo ${ }^{1}$ and Hapsari Setyowardhani ${ }^{2 *}$ \\ ${ }^{1,2}$ Universitas Indonesia, Depok, Indonesia
}

\begin{abstract}
As the Indonesia World Records Museum (MURI)'s 2019 winner of the category of fastest growing coffee shop in 2019, Janji Jiwa strives to maintain and increase its number of customers. This study replicates Kim and Lee's (2016) research on how coffee shops in South Korea increase their brand loyalty. It employs the purposive sampling method with 206 respondents and analysis is conducted using Structural Equation Modeling (SEM). The findings of the study reveal that customer brand identification has a positive effect on brand involvement, but no positive effect on brand-decision involvement. Both self-congruity and service value have a positive effect on brand involvement and brand-decision involvement. In addition, brand involvement and brand-decision involvement have a positive effect on brand satisfaction and brand loyalty. Finally, brand satisfaction has a positive effect on brand loyalty. Managerial implications and recommendations related to these findings will be discussed further in order to guide future research.
\end{abstract}

Keywords: Brand Loyalty, Brand Satisfaction, Coffee Shop, Customer-Brand Identification, Involvement, Self Congruity, Service Value

\section{Introduction}

Indonesia is one of the countries with the highest coffee consumption in the world. ICO noted that in the 2016/2017 period this reached 4.6 million packs (per 60 $\mathrm{kg}$ ), making it 6 th in the ranking of countries with the highest coffee consumption, after Russia. The largest coffee consumption in the world is among countries that are members of the European Union, with a consumption of more than 42.6 million packages.

Considering their spread in Indonesia, this study focuses on coffee shops, especially in the Jakarta metropolitan area (Jabodetabek). Moreover, coffee shops are one type of business that requires relatively little capital and are easy to run, without having to have complicated coffee processing skills. Moreover, the coffee shop business that can reach all levels of society, from middle-low to middle-upper class, which makes them relatively attractive to Indonesians.

This study replicates the research conducted by Kim \& Lee (2017) entitled "Promoting Customers' Involvement With Service Brands: Evidence From Coffee Shop Customers". In their study, they found that coffee shop managers must understand their business well amidst the massive growth of such shops in South Korea due to the fact that they are very easy to start up and are very popular.

However, one of the main problems in managing a coffee shop is the high failure rate because of the intense competition (Kim \& Lee, 2017). Therefore, one of the reasons why many coffee shops do not survive in the long term is due to industry standardization, which makes it difficult for them to differentiate between customer and company relationships between coffee shops (Cha et al ., 2015, Choi et al., 2017).

* Corresponding author. Email address: hapsari.setyowardhani@ui.gmail.com 


\section{Theoretical Review}

In general, involvement shows the degree of perceived relevance and importance associated with an object, which makes it valuable to an individual. Customer involvement can take the form of an individual state (motivation/interest) (Huang et al., 2010); a process (eternal ) (Huang et al., 2010; Kinard and Capella, 2010); and/or serve as a moderator between relationships (San Martin et al., 2011). The concept of engagement has been applied to the context of advertising (Lee et al., 2015), purchasing decisions (Bojanic \& Warnick, 2012), and/or the service industry (Kinard \& Capella, 2010).

Based on Laaksonen's (1994) research, this study investigates three different approaches to examining the factors that influence customer engagement with service brands. Laaksonen proposes three categories of engagement:

a. Cognitive-based involvement approaches; for example, psychological ties between the individual and the stimulus object;

b. The individual-state involvement approach, which is the inherent potential of a situation to attract the attention of individuals on their behavior in that situation; and

c. The response-based involvement approach, that is, the point of view related to information processing.

Based on Mittal and Lee (1989), there are two different types of brand involvement, namely:

a. Brand involvement or product involvement, related to the brand itself, with a focus on whether the brand meets the consumer's consumption objectives. Brand or product involvement can also be defined as the interest of consumers in a product class, which comes from their perception that the product class meets their values and goals in consuming certain brand products; and

b. Brand-decision involvement or purchase involvement, which describes the customer's purchasing decision on a brand in this study. Brand-decision or purchase involvement can also be defined as making a selection when choosing a brand. A low level of brand-decision involvement implies weak brand selection, whereas a high level implies a very strong choice of brand.

Brand satisfaction refers to the overall satisfaction of customers with a brand, based on all interactions with service providers (Olsen, 2007). When customers are satisfied with a brand, they are more likely to have higher brand loyalty (Li \& Petrick, 2008). Brand loyalty is defined as a condition in which consumers have a positive assessment of a brand, have a commitment to it, and have a tendency to repurchase products from the brand in the future (Mowen, 1995). Therefore, brand loyalty is highly influenced by the level of consumer satisfaction or dissatisfaction with certain brands.

\section{Research Method}

This research adopts a conclusive descriptive approach, utilizing both primary and secondary data. The primary data were collected through survey questionnaires distributed to customers of the Janji Jiwa coffee shop who had visited and consumed coffee there three times or more. 206 out of the 211 questionnaires were valid. Meanwhile, the secondary data were gathered from journals, books, and online news articles related to the variables used in this study. 
The study replicates that conducted by Kim \& Lee (2017), entitled "Promoting Customers' Involvement With Service Brands: Evidence From Coffee Shop Customers" based on the following research model.

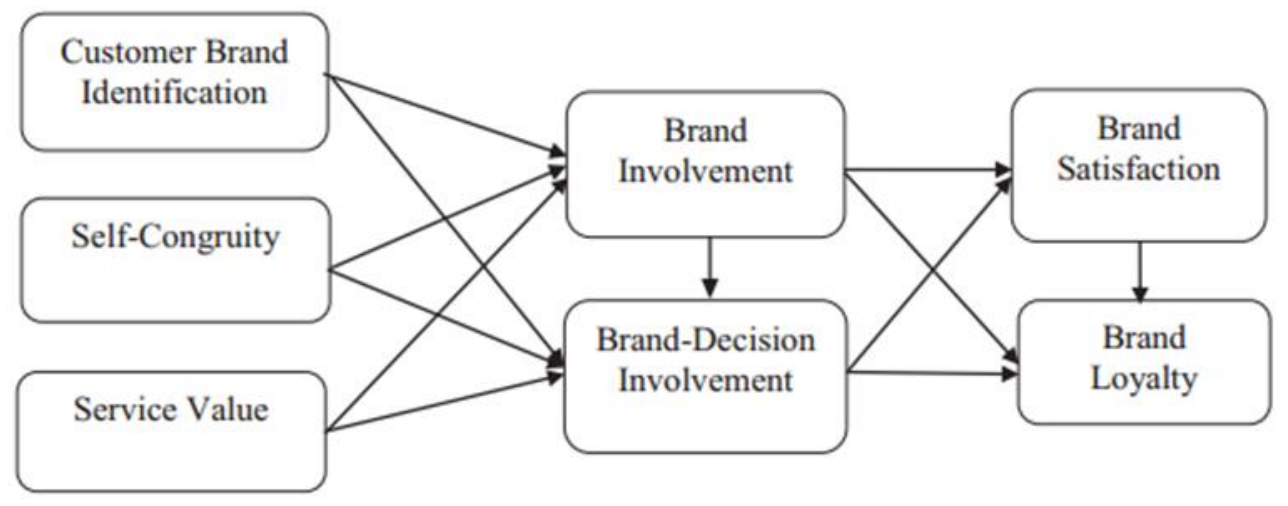

Figure 1 Research Model

Source : Son-Ho and Seonjeong (2016)

For this study, the researchers made modifications to the research object. The previous research by Kim and Lee (2017) focused on more than eight leading coffee shops in South Korea, including Starbucks, Caffebene, Coffee Bean, Angel-In. -Us, Hollys, Ediya Coffee, Tom N Toms, and several other independent coffee shops. This study, however, only examines the Janji Jiwa coffee shop. However, the research model, research variables and question items employed are similar to those used by Kim and Lee (2017).

A pre-test was conducted by distributing research questionnaires to 30 respondents as a sample to ascertain whether the research instrument could be applied in further research. For this reason, it was necessary to first calculate the validity and reliability of each indicator. The main test in this study employed Structural Equation Modeling (SEM). To determine how well the observed variables represent each construct, measurement model and structural model analysis were performed.

The study includes nine hypotheses:

H1. Customer-brand identification has a positive effect on (a) brand involvement and (b) brand-decision involvement;

H2. Self-congruity has a positive effect on (a) brand involvement and (b) branddecision involvement;

H3. Service value has a positive effect on (a) brand involvement and (b) brand-decision involvement;

H4. Brand involvement has a positive effect on brand-decision involvement;

H5. Brand involvement has a positive effect on brand satisfaction;

H6. Brand-decision involvement has a positive effect on brand satisfaction;

H7. Brand involvement has a positive effect on brand loyalty;

H8. Brand-decision involvement has a positive effect on brand loyalty; and

H9. Brand satisfaction has a positive effect on brand loyalty.

\section{Results}

The minimum, maximum, total (total value), average, and average total answers of each variable item responded to by the 206 participating respondents were observed. 
AFEBI Management and Business Review (AMBR)

Vol.04 No.02, December 2019

Table 1 Descriptive Variable Analysis

\begin{tabular}{|c|c|c|c|c|c|c|}
\hline Indicator & $\mathbf{N}$ & Minimum & Maximum & Sum & Mean & $\begin{array}{l}\text { Total } \\
\text { Mean }\end{array}$ \\
\hline \multicolumn{7}{|c|}{ Customer-brand Identification } \\
\hline CBI1 & 206 & 1 & 5 & 795 & 3,85 & \multirow[t]{4}{*}{3,72} \\
\hline CBI2 & 206 & 1 & 5 & 788 & 3,82 & \\
\hline CBI3 & 206 & 1 & 5 & 751 & 3,65 & \\
\hline CBI4 & 206 & 1 & 5 & 731 & 3,55 & \\
\hline \multicolumn{7}{|c|}{ Self-congruity } \\
\hline SC1 & 206 & 1 & 5 & 513 & 2,49 & \multirow[t]{4}{*}{2,43} \\
\hline $\mathrm{SC} 2$ & 206 & 1 & 5 & 495 & 2,40 & \\
\hline SC3 & 206 & 1 & 5 & 504 & 2,45 & \\
\hline SC4 & 206 & 1 & 5 & 494 & 2,39 & \\
\hline \multicolumn{7}{|c|}{ Service Value } \\
\hline SV1 & 206 & 1 & 5 & 822 & 3,99 & \multirow[t]{5}{*}{3,98} \\
\hline SV2 & 206 & 1 & 5 & 804 & 3,90 & \\
\hline SV3 & 206 & 1 & 5 & 879 & 4,27 & \\
\hline SV4 & 206 & 1 & 5 & 802 & 3,89 & \\
\hline SV5 & 206 & 1 & 5 & 789 & 3,83 & \\
\hline \multicolumn{7}{|c|}{ Brand Involvement } \\
\hline BI1 & 206 & 1 & 5 & 496 & 2,41 & \multirow[t]{5}{*}{2,40} \\
\hline $\mathrm{BI} 2$ & 206 & 1 & 5 & 469 & 2,28 & \\
\hline BI3 & 206 & 1 & 5 & 507 & 2,46 & \\
\hline BI4 & 206 & 1 & 5 & 501 & 2,43 & \\
\hline BI5 & 206 & 1 & 5 & 499 & 2,42 & \\
\hline \multicolumn{7}{|c|}{ Brand-decision Involvement } \\
\hline BDI1 & 206 & 1 & 5 & 693 & 3,36 & \multirow[t]{4}{*}{3,43} \\
\hline BDI2 & 206 & 1 & 5 & 693 & 3,36 & \\
\hline BDI3 & 206 & 1 & 5 & 708 & 3,44 & \\
\hline BDI4 & 206 & 1 & 5 & 733 & 3,56 & \\
\hline \multicolumn{7}{|c|}{ Brand Satisfaction } \\
\hline BS1 & 206 & 1 & 5 & 788 & 3,82 & \multirow[t]{5}{*}{3,75} \\
\hline BS2 & 206 & 1 & 5 & 762 & 3,70 & \\
\hline BS3 & 206 & 1 & 5 & 777 & 3,77 & \\
\hline BS4 & 206 & 1 & 5 & 763 & 3,70 & \\
\hline BS5 & 206 & 1 & 5 & 768 & 3,73 & \\
\hline \multicolumn{7}{|c|}{ Brand Loyalty } \\
\hline BL1 & 206 & 1 & 5 & 782 & 3,80 & \multirow[t]{4}{*}{3,66} \\
\hline BL2 & 206 & 1 & 5 & 735 & 3,57 & \\
\hline BL3 & 206 & 1 & 5 & 754 & 3,66 & \\
\hline BL4 & 206 & 1 & 5 & 743 & 3,61 & \\
\hline
\end{tabular}

Furthermore, a causal relationship analysis was conducted to observe the influence of the variables on each other. To do this, the t-value and the equation coefficient, or $\left(\mathrm{R}^{2}\right)$, were examined.

Tabel 2 T-Values of the Structural Model

\begin{tabular}{c|l|c|c}
\hline Hypotheses & \multicolumn{1}{|c|}{ Hypotheses Statement } & T-value & Conclusion \\
\hline H1a & $\begin{array}{l}\text { Customer-brand identification has a positive effect } \\
\text { on brand involvement }\end{array}$ & $\mathbf{4 , 0 2}$ & Significant \\
\hline H1b & $\begin{array}{l}\text { Customer-brand identification has a positive effect } \\
\text { on brand-decision involvement }\end{array}$ & $\mathbf{- 0 , 5 6}$ & Not Significant \\
\hline H2a & $\begin{array}{l}\text { Self-congruity has a positive effect on brand } \\
\text { involvement }\end{array}$ & $\mathbf{3 , 7 9}$ & Significant \\
\hline
\end{tabular}


Analysis of Factors Affecting Brand Loyalty: A Case Study of Janji Jiwa Coffee

\begin{tabular}{|c|c|c|c|}
\hline H2b & $\begin{array}{l}\text { Self-congruity has a positive effect on brand- } \\
\text { decision involvement }\end{array}$ & 2,28 & Significant \\
\hline H3a & $\begin{array}{l}\text { Service value has a positive effect on brand } \\
\text { involvement }\end{array}$ & 3,39 & Significant \\
\hline H3b & $\begin{array}{l}\text { Service value has a positive effect on brand- } \\
\text { decision involvement }\end{array}$ & 6,04 & Significant \\
\hline H4 & $\begin{array}{l}\text { Brand involvement has a positive effect on brand- } \\
\text { decision involvement }\end{array}$ & 3,12 & Significant \\
\hline H5 & $\begin{array}{l}\text { Brand involvement has a positive effect on brand } \\
\text { satisfaction }\end{array}$ & 2,06 & Significant \\
\hline H6 & $\begin{array}{l}\text { Brand-decision involvement has a positive effect } \\
\text { on brand satisfaction }\end{array}$ & 7,81 & Significant \\
\hline H7 & $\begin{array}{l}\text { Brand involvement has a positive effect on brand } \\
\text { loyalty }\end{array}$ & 1,92 & Significant \\
\hline H8 & $\begin{array}{l}\text { Brand-decision involvement has a positive effect } \\
\text { on brand loyalty }\end{array}$ & 2,39 & Significant \\
\hline H9 & $\begin{array}{l}\text { Brand satisfaction has a positive effect on brand } \\
\text { loyalty }\end{array}$ & 7,18 & Significant \\
\hline
\end{tabular}

Source : Lisrel Output Analysis

From the Lisrel output processed, it was found that eleven of the twelve hypotheses on the relationship between the variables had t-values of $\geq 1.645$, namely $\mathrm{H} 1 \mathrm{a}=4.02, \mathrm{H} 2 \mathrm{a}=3.79, \mathrm{H} 2 \mathrm{~b}=2.28, \mathrm{H} 3 \mathrm{a}=3.39, \mathrm{H} 3 \mathrm{~b}=6.04, \mathrm{H} 4=3.12, \mathrm{H} 5=2.06$, $\mathrm{H} 6=7.81, \mathrm{H} 7=1.92, \mathrm{H} 8=2.39$ and $\mathrm{H} 9=7.18$, which indicates that there is a significant relationship between the variables in the related hypothesis. Besides, one of the twelve research hypotheses does not meet the requirements for significant influence, with a $t$-value that does not meet the requirements of $\geq 1.645$ or $\leq-1.645$, namely $\mathrm{H} 1 \mathrm{~b}=-0.33$, which indicates that the relationship between the related variables in the hypothesis is not significant.

\section{Discussion}

The individual state of customer involvement can represent an individual's behavior (Laaksonen, 1994). Self-congruity describes the approach to individual circumstances. Customers tend to infer their self-image and/or self-identity through their consumption experiences. For example, self-congruity explains that customers are more likely to buy a product brand when the brand matches their image. Ladik, et.al.(2015) describes how assets can represent themselves, express individual personal achievements, and show social status.

Customers' views about themselves can be related to the services they use, such as the coffee shops they visit (Kim \& Jang, 2014). This implies that customers recognize their self-concept through the consumption of coffee brands due to the symbolic nature of the coffee industry.

A response-based approach can explain how customers process and evaluate external information during the service provision process. Customer-perceived value represents a response-based approach. The exchange process is dynamic in the service industry due to the evolving interactions between service providers and customers (Sierra \& McQuitty, 2005). Perceived value refers to a customer's overall assessment of a product or brand based on its benefits and costs (Zeithaml, 1988), while service value describes the various service components that shape customer value perceptions by the trade-off between what customers receive and what they provide.

Kim and Jang (2014) suggest that coffee shop customers tend to fulfil their values (materialism), social values, and functional values through consumption. They identify trends in symbolic consumption related to individual and social values that ultimately influence customer coffee shop loyalty. Therefore, it is estimated that when customers perceive value during their consumption processes, such as competitive pricing or high quality, they are more likely to be involved with brands and brand decisions. 


\section{Recommendations}

It is acknowledged that the research contains some limitations. Therefore, the following recommendations are suggested for researchers conducting further studies to improve these:

a. Develop and modify the model by adding either independent or moderating variables that are relevant to the research context.

b. Conduct research in different industrial contexts to confirm the application of this model to these.

c. The research object in this study is only the Janji Jiwa coffee shop; in the future research could be carried out on several other leading coffee shops in Jabodetabek and Indonesia.

d. The selection of respondents should represent more types of consumers to better describe the entire age group, occupation, and income.

e. Screen the questionnaire respondents by asking whether they consume Janji Jiwa products by buying them or obtaining them free. This is because such a difference could produce bias when completing the survey due to the question of whether or not the respondents had made sacrifices.

\section{References}

Bojanic, D., \&Warnick, R. (2012). The Role Of Purchase Decision Involvement In A Special Event. Journal of Travel Research, 51 (3), 357-366. https://doi.org/10.1177/0047287511418364

Cha, M., Yi, Y., \& Bagozzi, R. (2015). Effects Of Customer Participation In Corporate Social Responsibility Programs On The CSR-Brand Fit And Brand Loyalty. Cornell Hospitality Quarterly, 57(3), 1-15. https://doi.org/10.1177/1938965515620679

Choi, Y., Ok, J., \& Hyun, S. (2017). Relationships between brand experiences, personality traits, prestige, relationship quality, and loyalty: an empirical analysis of coffeehouse brands. International Journal of Contemporary Hospitality Management, 29(4), 1185-1202.

Huang, C. Y., Chou, C. J., \& Lin, P. C. (2010). Involvement Theory In Constructing Bloggers' Intention To Purchase Travel Products. Tourism Management, 31, 513-526. 10.1016/j.tourman.2009.06.003.

Kim, D., \& Jang, S. (2014). Motivational drivers for status consumption: A study of Generation Y consumers. International Journal of Hospitality Management. 38. 39-47. 10.1016/j.ijhm.2013.12.003.

Kim, S. H., \& Lee, S (Ally). (2017). Promoting Customers' Involvement With Service Brands: Evidence From Coffee Shop Customers. Journal of Service Marketing, 31(7), 12.

Kinard, B. R., \& Capella, M. (2010). Relationship Marketing: The Influence Of Consumer Involvement On Perceived Service Benefits. Journal of Services Marketing. 31(4), 513-526. 10.1108/08876040610691257

Laaksonen, P. (1994). Consumer Involvement: Concepts and Research. Routledge. 
Ladik, D., Carrillat, F., \& Tadajewski, M. (2015). Belk's (1988) "Possessions and the extended self" revisited. Journal of Historical Research in Marketing, 7, 184207. 10.1108/JHRM-06-2014-0018.

Lee, S., Kim, K., \& Sundar, S. (2015). Customization In Location-Based Advertising: Effects Of Tailoring Source, Locational Congruity, And Product Involvement On Ad Attitudes. Computers in Human Behavior, 51, 336-343.

Li, X., \& Petrick, J. (2008). Examining the Antecedents of Brand Loyalty from an Investment Model Perspective. Journal of Travel Research. J TRAVEL RES. 47. 25-34. 10.1177/0047287507312409.

Mittal, B., \& Lee, M. S. (1989). A Causal Model Of Consumer Involvement. Journal of Economic Psychology, 10(3), 363-389. https://doi.org/10.1016/0167$\underline{4870(89) 90030-5}$

Mowen, J. C. (1995). Consumer Behavior. Pearson.

Olsen, S. (2007). Repurchase Loyalty: The Role Of Involvement And Satisfaction. Psychology and Marketing, 24, 315 - 341. 10.1002/mar.20163.

San Martín, S., San José, R., \& Camarero, C. Does Involvement Matter in Online Shopping Satisfaction and Trust? (2011). Psychology and Marketing. 28(2). 10.1002/mar.20384

Sierra, J., \& Mcquitty, S. (2005). Service Providers And Customers: Social Exchange Theory And Service Loyalty. Journal of Services Marketing, 19. 392-400. $10.1108 / 08876040510620166$.

Zeithaml, V. (1988). Consumer Perceptions of Price, Quality and Value: A Means-End Model and Synthesis of Evidence. Journal of Marketing, 52. 2-22. $10.1177 / 002224298805200302$. 